\title{
ANALISIS KANDUNGAN LOGAM BERAT TIMBAL (Pb) PADA CABAI MERAH (CAPSICUM ANNUUM L) YANG BEREDAR DI PASAR BATUSANGKAR
}

\author{
Kuntum Khaira \\ Jurusan Tadris Kimia Institut Agama Islam Negeri Batusangkar \\ Jalan Sudirman No. 137 Lima Kaum Batusangkar \\ Email: kuntum60@gmail.com
}

\begin{abstract}
Research has been conducted to analyze the conten of the heavy metal content of lead $(\mathrm{Pb})$ in red pepper (Capsicum Annuum L) circulating in Batusangkar market. Samples of five red peppers were taken from different places in Batusangkar market. The sample was dissolved by using a mixture of sulfuric acid and nitric acid. Furthermore, lead was measured by using atomic absorption spectrophotometry (SSA) at a wavelength of $283.3 \mathrm{~nm}$. The results of the analysis showed that the lowest lead level of $0.2386 \mathrm{mg} / \mathrm{kg}$ and the highest lead level of $0.73642 \mathrm{mg} / \mathrm{kg}$. From the five samples, it was found that there was one sample whose lead level exceeded the maximum limit set by National Standardization Council of 2009 about maximum limit of heavy metal contamination in food that is $0,5 \mathrm{mg} / \mathrm{kg}$ for lead, whereas for 4 other sample the value of lead level is less from $0.5 \mathrm{mg} / \mathrm{kg}$. In addition, from the five samples, one sample did not meet the safe criteria and the other four samples meet the criteria.
\end{abstract}

Key words: Heavy metal, lead $(\mathrm{Pb})$, red pepper.

\section{PENDAHULUAN}

Hortikultura merupakan salah satu sektor yang berkembang pesat dalam pertanian Indonesia. Komoditas hortikultura merupakan komoditas yang penting dan strategis karena jenis komoditas ini merupakan kebutuhan pokok manusia yang hakiki yang setiap saat hendaknya selalu tersedia dengan jumlah yang cukup, mutu yang layak, aman dikonsumsi dan dengan harga yang terjangkau oleh masyarakat.

Salah satu komoditas hortikultura yang menjadi komoditas unggulan nasional adalah cabai karena merupakan komoditas yang sangat dibutuhkan oleh hampir semua orang dari berbagai lapisan masyarakat. Pada umumnya masyarakat mengenal dua jenis cabai yaitu cabai besar (capsicum annuum L) yaitu cabai merah besar dan cabai merah keriting serta jenis cabai kecil atau cabai rawit (capsicum frutescens). Sebagian besar penduduk Indonesia mengkonsumsi cabai dalam bentuk segar, kering dan olahan.

Cabai juga sangat melekat dengan budaya Indonesia dalam bentuk kuliner nusantara. Hampir semua jenis masakan di Indonesia mengunakan cabai, baik sebagai pelengkap masakan ataupun sebagai bumbu. Untuk kalangan masyarakat tertentu seperti masyarakat minang cabai bahkan dianggap sebagai bahan makanan pokok yang tidak bisa dipisahkan dalam kehidupan sehari-hari. Selain itu cabai juga dibutuhkan di sentra industri seperti industri saos dan mie instan. Diperkirakan kebutuhan cabai di Indonesia akan selalu meningkat seiring dengan meningkatnya pertambahan penduduk setiap tahunnya, semakin beragamnya kebutuhan 
serta sebagian penduduk Indonesia merupakan pengemar masakan pedas.

Tanaman cabai banyak dibudidayakan di Indonesia karena Indonesia memiliki iklim yang tropis. Cabai merah dapat ditanam di dataran tinggi ataupun dataran rendah hingga pesisir pantai. Beberapa daerah penghasil cabai merah di Indonesia antara lain Banten, Cianjur, Tasikmalaya, Brebes, Lombok, Sumatra Utara, Sumatra Barat dan beberapa daerah lainnya. Untuk Sumatera Barat produksi cabai terus meningkat dari tahun ke tahun. Berdasarkan berita resmi statistik BPS Sumatera Barat No. 46/8/13 Th VII tanggal 4 Agustus 2014 produksi cabai besar Sumatera Barat tahun 2011 adalah 48874 ton pertahun, tahun 2012 sebanyak 57671 ton pertahun, dan tahun 2013 sebanyak 60981 ton pertahun. Kabupaten Tanah Datar sebagai salah satu kabupaten di Provinsi Sumatera Barat menempati urutan ketiga dalam hal produksi cabai besar setelah Kabupaten Solok dan Kabupaten Agam.

Cabai mengandung karbohidrat, protein, lemak, vitamin $\mathrm{A}, \mathrm{C}, \mathrm{B} 1$ dan mineral seperti kalsium, fosfor dan besi. Cabai berkhasiat mengobati berbagai macam penyakit seperti reumatik, sariawan, sakit gigi, flu, dan dapat pula sebagai stomatik atau peningkat nafsu makan. Cabai juga dapat mencegah penyakit strok dan jantung koroner karena capsaicin (komponen pemberi rasa pedas pada cabai) bersifat anti koagulan yang bekerja untuk menjaga darah agar tetap encer dan mencegah terbentuknya kerak lemak pada pembuluh darah (Hermanto, 2011).

Mengingat pentingnya cabai sebagai bahan pangan, maka harus memenuhi kriteria ASUH (Aman, Sehat, Utuh dan Halal) sesuai dengan konsep manjemen mutu pangan. Untuk kriteria aman maka cabai harus bebas dari bahan beracun dan berbahaya sehingga tidak berdampak buruk terhadap masyarakat sebagai konsumen. Diantara bahan beracun dan berbahaya yang dapat terkandung dalam cabai adalah logam berat. Pencemaran logam berat pada cabai dapat berasal dari penggunaan pupuk, pestisida, serta polusi udara.

Salah satu logam berat yang dapat mengkontaminasi cabai adalah timbal $(\mathrm{Pb})$.
Kemungkinan adanya timbal yang terkandung dalam cabai cukup besar karena timbal dapat bersumber dari penggunaan pupuk, pestisida, serta polusi udara. Timbal dalam kehidupan sehari-hari lebih dikenal dengan nama timah hitam. Nama ilmiah dari timbal adalah plumbum dan dilambangkan dengan $\mathrm{Pb}$. Timbal merupakan logam yang sangat beracun jika terserap kedalam tubuh. Kandungan timbal yang diperbolehkan untuk buah dan sayur sesuai Standar Nasional Indonesia (SNI) 7387:2009 mengenai Batas Maksimum Cemaran Logam Berat dalam Pangan adalah maksimal $0,5 \mathrm{mg} / \mathrm{kg}$. Kandungan timbal yang melebihi batas aman yang telah ditentukan akan menimbulkan efek buruk terhadap kesehatan konsumen.

Timbal dapat masuk kedalam tubuh manusia melalui saluran pernafasan atau saluran pencernaan menuju sistem peredaran darah kemudian menyebar keberbagai jaringan lain seperti ginjal, hati, tulang, otak dan saraf. Keracunan timbal pada orang dewasa ditandai dengan 3P yaitu pallor (pucat), pain (sakit) dan paralysis (kelumpuhan). Pada keracunan kronik mula-mula logam berat tidak menyebabkan gangguan kesehatan yang tampak tetapi efek toksik makin lama makin menumpuk hingga akhirnya terjadi gejala keracunan. Keracunan timbal kronik ditandai dengan depresi, sakit kepala, sulit berkonsentrasi, daya ingat terganggu dan sulit tidur. Sedangkan keracunan akut terjadi jika timbal masuk kedalam tubuh seseorang lewat makanan atau minuman atau menghirup uap timbal dalam waktu relatif pendek dengan dosis atau kadar yang lebih tinggi. Gejala yang timbul berupa mual, muntah kelainan fungsi otak, anemia, kerusakan ginjal bahkan kematian dalam waktu 1-2 hari (Widianingrum, 2007)

Keracunan timbal pada anak-anak dapat mengurangi kecerdasan. Bila kadar timbal dalam darah anak mencapai tiga kali batas normal maka akan menyebabkan penurunan kecerdasan intelektual (IQ) dibawah 80. Kelainan fungsi otak terjadi karena timbal secara kompetitif menggantikan peran mineralmineral utama dalam tubuh seperti tembaga, 
seng, besi dalam mengatur fungsi sistem saraf pusat. Wanita yang terpapar timbal juga memiliki resiko besar menularkan kepada anaknya selama masa kehamilan atau menyusui karena timbal yang dicerna oleh ibu dapat mengalir melalui plasenta dan berakibat fatal pada janin (Suheini, 2010).

Pencemaran udara yang berasal dari gas buangan sisa pembakaran bahan bakar kendaraan bermotor mengandung logam berat timbal. Bahan bakar kendaraan bermotor (bensin) mengandung zat aditif tetraetiltimbal atau tetrametil timbal atau campuran keduanya. Zat aditif ini berfungsi sebagai zat anti ketuk pada mesin kendaraan bermotor. Selain itu pada bensin juga ditambahkan senyawa etilen klorida dan etilen bromida. Selama proses pembakaran didalam mesin akan dikeluarkan hasil sampingan berupa timbal diklorida dan timbal dibromida yang dikeluarkan bersamaan dengan asap kendaraan bermotor. Senyawa timbal sisa pembakaran bahan bakar kendaraan bermotor ini akan membentuk partikulat dan diserap oleh tumbuh-tumbuhan (Pallar, 1994).

Yandrilita (2015) melakukan penelitian kandungan timbal pada buah tomat yang ditanam di pinggir jalan raya di Kota Bukittinggi dan didapatkan hasilnya bahwa kandungan timbal dalam buah tomat sebesar $1,0725 \mathrm{mg} / \mathrm{kg}$, artinya nilai ini telah melebihi batas aman kadar timbal yang diperbolehkan. Diduga kandungan timbal yang tinggi pada buah tomat disebabkan oleh polusi udara yang berasal dari gas buangan sisa pembakaran bahan bakar kendaraan bermotor. Penelitian lain dilakukan oleh Deni Agung Priandoko (2012) yang meneliti tentang kandungan timbal pada dua jenis sayuran yaitu sawi hijau dan wortel di Kota Denpasar. Diperoleh kandungan timbal pada kedua jenis sayuran tersebut $0,67 \mathrm{mg} / \mathrm{kg}$ dan $0,63 \mathrm{mg} / \mathrm{kg}$.

Sumber pencemaran timbal lainnya dilaporkan oleh Charlena (2004) yang meneliti kandungan logam berat timbal pada sayursayuran. Hasil penelitiannya menyebutkan bahwa penggunaan pupuk dan pestisida yang berlebihan dapat menjadi sumber pencemaran logam berat timbal didalam tanah.
Pupuk fosfat yang banyak digunakan oleh petani di Indonesia mengandung timbal berkisar $5-156 \mathrm{mg} / \mathrm{kg}$, sehingga konsentrasi timbal didalam tanah terus meningkat apabila dilakukan pemupukan secara terus menerus. Kemudian untuk menanggulangi hama guna melindungi lahan dan memaksimalkan hasil pertanian, petani menggunakan pestisida dan herbisida. Pada prakteknya masih banyak petani yang menggunakan pestisida menyalahi aturan seperti penggunaan pestisida secara berlebihan dengan dosis yang melebihi takaran, penggunaan pestisida yang dilarang beredar serta mencampur beberapa jenis pestisida dengan alasan untuk meningkatkan daya racunnya pada hama tanaman (Christina, 2010). Hal ini mengakibatkan terakumulasinya timbal didalam tanah. Kadar timbal yang tinggi dalam tanah akan diserap oleh akar tanaman dan didistribusikan kedalam jaringan tanaman.

Berdasarkan uraian diatas perlu dilakukan penelitian terhadap kandungan timbal yang ada pada cabai merah. Sampel cabai merah yang akan diteliti diambil dari Pasar Batusangkar. Metode yang akan digunakan untuk menganalisis kandungan timbal adalah metode Spektrofotometri Serapan Atom (SSA). Metode ini dipilih karena sangat spesifik untuk unsur yang akan dianalisis, sensitif dan waktu pengerjaan yang lebih cepat.

\section{METODE PENELITIAN}

Sampel cabai merah yang diteliti berjumlah 5 sampel yang diperoleh dari 5 pedagang berbeda di Pasar Batusangkar. Alatalat yang digunakan dalam penelitian ini adalah Spektrofotometer Serapan Atom (SSA), Hallow Cathode Lamp (HCL) timbal, oven, neraca analitis, kertas saring whatman no.42, dan peralatan gelas yang sering digunakan di laboratorium.Sedangkan bahan-bahan yang diperlukan dalam penelitian ini adalah sampel cabai, $\mathrm{HNO} 3$ pa, $\mathrm{H} 2 \mathrm{SO} 4$ pa, $\mathrm{Pb}(\mathrm{NO} 3) 2$ pa, dan air suling. 
Prosedur kerja pada penelitian ini adalah sebagai berikut (1) Preparasi sampel, dilakukan dengan mencuci seluruh sampel cabai dengan air suling kemudian ditiriskan untuk selanjutnya dihaluskan sampai homogen untuk diproses lebih lanjut. Jika sampel tidak langsung dianalisa, simpan dalam wadah tertutup rapat sampai saatnya untuk dianalisa(2) Pengeringan sampel ; Masingmasing sampel cabai ditimbang dalam cawan penguap.Selanjutnya dimasukkan kedalam oven dan panaskan pada suhu $105 \mathrm{oC}$ sampai didapatkan berat konstan. Setelah keringpindahkan cawan penguap kedalam desikator selama 30 menit. Lakukan penimbangan dan hitung kadar air.

(3) Destruksi Sampel ; Sampel cabai yang telah dikeringkan dimasukkan kedalam labu destruksi kemudian ditambahkan larutan $\mathrm{H} 2 \mathrm{SO} 4$ pa sebanyak $5 \mathrm{~mL}$. Untuk proses destruksi dilakukan pemanasan secara bertahap mulai dari panas yang terendah kemudian dinaikkan secara perlahan-lahan sampai larutan berwarna hitam. Setelah itu ditetesi larutan HNO3 pekat $10-20$ tetes sampai diperoleh larutan berwarna kekuningan. Hasil destruksi kemudian didinginkan dan diencerkan dengan air suling sampai volume $25 \mathrm{~mL}$ dan disaring dengan kertas saring whatman No.42. Larutan sampel siap diukur kandungan logam timbalnya menggunakan alat SSA (Dachriyanus, 2004).

(4) Pembuatan Larutan Standar Timbal ; Pembuatan larutan standar timbal dilakukan dengan langkah-langkah sebagai berikut: (a) Pembuatan larutan standar $\mathrm{Pb} 100 \mathrm{mg} / \mathrm{L}$, dipipet $5 \mathrm{~mL}$ larutan induk $\mathrm{Pb} 1000 \mathrm{mg} / \mathrm{L}$ dan dimasukkan ke dalam labu ukur $50 \mathrm{~mL}$, ditambahkan dengan air suling sampai tanda batas (b) Pembuatan larutan standar $\mathrm{Pb} 10$ $\mathrm{mg} / \mathrm{L}$, dipipet $5 \mathrm{~mL}$ larutan induk $\mathrm{Pb} 100 \mathrm{mg} / \mathrm{L}$ dan dimasukkan ke dalam labu ukur $50 \mathrm{~mL}$, ditambahkan dengan air suling sampai tanda batas (c) Pembuatan larutan standar $\mathrm{Pb} \mathrm{0,2} \mathrm{;}$
0,$4 ; 0,6 ; 0,8$ dan $1,0 \mathrm{mg} / \mathrm{L}$, dipipet masingmasing $1 \mathrm{~mL}, 2 \mathrm{~mL}, 3 \mathrm{~mL}, 4 \mathrm{~mL}$ dan $5 \mathrm{~mL}$ larutan standar $\mathrm{Pb} 10 \mathrm{mg} / \mathrm{L}$ dan dimasukkan masing-masing ke dalam labu ukur $50 \mathrm{~mL}$, di tambahkan air suling sampai tanda batas (d) Nilai absorbansinya di ukur dengan menggunakan SSA.

(5) Pengukuran konsentrasi logam timbal $(\mathrm{Pb})$ dengan SSA ; Pengukuran konsentrasi logam timbal $(\mathrm{Pb})$ dengan SSA dilakukan dengan tahapan sebagai berikut (SNI 2354.5-2011) : (a) Mengoptimalkan alat SSA sesuai petunjuk penggunaan alat (b) Beberapa parameter pengukur untuk logam timbal $(\mathrm{Pb})$ ditetapkan sebagai berikut yaitu panjang gelombang 283,3 nm, tipe nyala asetilen/udara (c) Kemudian masing-masing larutan standar yang telah di buat di ukur pada panjang gelombang 283,3 nm. Nilai absorbansinya akan terlihat (d) Buat kurva kalibrasi untuk mendapatkan persamaan garis regresi (e) Dilanjutkan dengan pengukuran sampel yang sudah dipersiapkan

(6) Pengukuran sampel ; Sampel hasil destruksi selanjutnya diukur serapan timbalnya dengan kombinasi yang sesuai dengan pengukuran standar timbal. Konsentrasi larutan sampel ditentukan dengan bantuan kurva kalibrasi larutan standar.

\section{HASIL DAN PEMBAHASAN}

\section{Pengukuran Absorbansi Larutan Standar Timbal $(\mathbf{P b})$}

Pengukuran kadar timbal $(\mathrm{Pb})$ pada sampel cabai dimulai dengan pengukuran absorbansi larutan standar timbal $(\mathrm{Pb})$ dengan spektrofotometri serapan atom (SSA). Data hasil pengukuran absorbansi dari larutan standar timbal $(\mathrm{Pb})$ diplotkan terhadap konsentrasi larutan timbal $(\mathrm{Pb})$ tertera pada tabel 1 berikut 
Khaira, K. 2017. Analisis Kandungan Logam Berat Timbal (Pb) pada Cabai Merah (capsicum annumm l) yang Beredar di Pasar Batusangkar. Journal of Sainstek 9(2): 94-102

Tabel 1. Data Hasil Pengukuran Absorbansi Larutan Standar timbal (Pb)

\begin{tabular}{ccc}
\hline No & Konsentrasi $(\mathrm{mg} / \mathrm{L})=\mathrm{X}$ & Absorbansi Rata-Rata $(\mathrm{A})=\mathrm{Y}$ \\
\hline 1 & 1,000 & 0,0468 \\
2 & 2,000 & 0,0892 \\
3 & 3,000 & 0,1304 \\
4 & 4,000 & 0,1683 \\
5 & 5,000 & 0,2081 \\
\hline
\end{tabular}

\section{Penentuan Persamaan Garis Regresi Larutan Standar Timbal (Pb)}

Dari absorbansi larutan standar yang diperoleh maka persamaan garis regresi dapat ditentukan dengan menggunakan metoda Least Square sebagai berikut :

Tabel 2. Data Perhitungan Persamaan Garis Regresi Larutan standar Timbal $(\mathrm{Pb})$

\begin{tabular}{rcccc}
\hline No & X & Y & X Y & $X^{2}$ \\
\hline 1 & 1,000 & 0,0468 & 0,0468 & 1 \\
2 & 2,000 & 0,0892 & 0,1784 & 4 \\
3 & 3,000 & 0,1304 & 0,3912 & 9 \\
4 & 4,000 & 0,1683 & 0,6732 & 16 \\
5 & 5,000 & 0,2081 & 1,0405 & 25 \\
$\Sigma$ & 15,000 & 0,6428 & 2,3301 & 55 \\
\hline
\end{tabular}

Dimana : $\quad \mathrm{x}=\frac{(\mathrm{xx})}{\mathrm{n}}=\frac{15,000}{5}=3,000$

$$
\mathrm{y}=\frac{(\mathrm{xy})}{\mathrm{n}}=\frac{0,6428}{\mathrm{~s}}=0.12856
$$

Persamaan garis regresi untuk kurva kalibrasi dapat diturunkan dari persamaan garis :

$$
\begin{aligned}
y & =a x+b \\
\operatorname{dimana}: & a=\text { slope } \\
\mathrm{b} & =\text { intersep }
\end{aligned}
$$

Harga a diperoleh dengan mensubstitusikan nilai-nilai yang terdapat dalam tabel 3 kedalam persamaan berikut :

$$
\mathrm{a}=\frac{\mathrm{n}(\mathrm{\Sigma xy})-(\mathrm{zx})(\mathrm{z} y]}{\mathrm{n}\left(\mathrm{\Sigma} \mathrm{x}^{2}\right)-(\mathrm{zx})^{2}}
$$

$\mathrm{a}=\frac{5(2.3301)-(15,000)(0.6428)}{5(55)-(15)^{2}}$

$$
\text { a }=0,04017
$$

Sedangkan harga $\mathrm{b}$ adalah :

$$
\begin{aligned}
& b=\bar{y}-a \bar{x} \\
& b=0,12856-(0,04017)(3,000) \\
& b=0,00805
\end{aligned}
$$

Sehingga persamaan garis regresinya adalah $\mathrm{y}=0,04017 \mathrm{x}+0,00805$. Dari persamaan garis regresi tersebut dibuat kurva kalibrasi antara konsentrasi dengan absorbansi. Berikut ini kurva kalibrasi laruran standar timbal $(\mathrm{Pb})$ 
Khaira, K. 2017. Analisis Kandungan Logam Berat Timbal (Pb) pada Cabai Merah (capsicum annumm l) yang Beredar di Pasar Batusangkar. Journal of Sainstek 9(2): 94-102

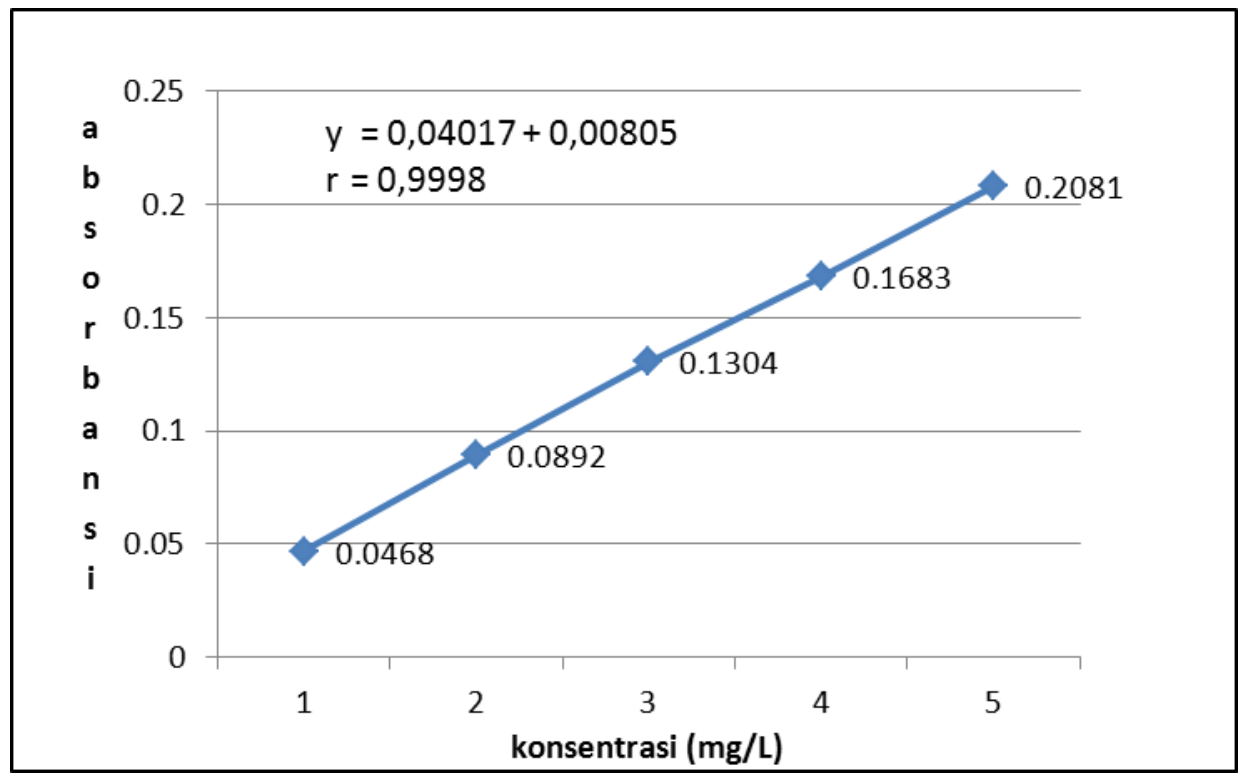

Gambar 1. Kurva kalibrasi larutan standar timbal $(\mathrm{Pb})$

Diperolehnya gambar 1 dari persamaan garis regresi linier hubungan antara absorbansi dan konsentrasi larutan standar sebagai berikut : $\mathrm{y}=0,04017 \mathrm{x}+0,00805$ dimana $\mathrm{y}=$ nilai absorbansi dan $\mathrm{x}=$ kandungan kadar timbal $(\mathrm{Pb})$. Nilai koefisien korelasi $(\mathrm{r}$ ) sebesar 0,9998. Hasil ini menunjukkan bahwa antara kandungan timbal $(\mathrm{Pb})$ dalam konsentrasi absorbansi berkorelasi positif dan korelasinya erat $(r=0,9998)$. Nilai $r$ sebesar 0,9998 berarti kurva pada gambar tersebut mempunyai keakuratan dalam menentukan konsentrasi sebesar 99,98 \%. (Rahmi,2013). Selanjutnya untuk menentukan kadar timbal $(\mathrm{Pb})$ dalam sampel cabai dilakukan pengukuran absorbansi dari masing-masing sampel.

Penentuan Kadar (mg/L) Timbal dalam Sampel Cabai Merah

Sampel yang akan diukur kadar timbalnya didestruksi terlebih dahulu dengan menggunakan campuran asam yaitu asam sulfat, $\mathrm{H}_{2} \mathrm{SO}_{4}$ dan asam nitrat, $\mathrm{HNO}_{3}$.Untuk menentukan kadar ( $\mathrm{mg} / \mathrm{L})$ timbal dalam sampel maka dilakukan pengukuran absorbansi dari masing-masing sampel . Berdasarkan persamaan yang diperoleh antara absorbansi dan larutan standar timbal $(\mathrm{Pb})$ yaitu $\mathrm{y}=$ $0,04017 \mathrm{x}+0,00805$ maka diperoleh hasil seperti ditunjukkan oleh tabel 3 berikut :

Tabel 3. Hasil Konsentrasi Timbal dalam Sampel

\begin{tabular}{cccc}
\hline No & Sampel & $\mathrm{y}$ & $\mathrm{x}$ \\
\hline 1 & $\mathrm{~A}$ & 0,0116 & 0,08837 \\
2 & $\mathrm{~B}$ & 0,0096 & 0,03859 \\
3 & $\mathrm{C}$ & 0,0102 & 0,05352 \\
4 & $\mathrm{D}$ & 0,0092 & 0,02863 \\
5 & $\mathrm{E}$ & 0,0093 & 0,03112 \\
\hline
\end{tabular}


Khaira, K. 2017. Analisis Kandungan Logam Berat Timbal (Pb) pada Cabai Merah (capsicum annumm l) yang Beredar di Pasar Batusangkar. Journal of Sainstek 9(2): 94-102

Penentuan Kadar Timbal (Pb) dalam dalam sampel (bobot kering) (mg/kg) dapat Sampel (bobot kering) (mg/kg)

ditentukan dengan menggunakan perbandingan

Kadar Timbal $(\mathrm{Pb})$ dalam Sampel (bobot kering) (mg/kg) merupakan kadar timbal dalam sampel cabai yang telah dikeringkan dengan cara dipanaskan dalam oven sehingga kandungan airnya sudah hilang. Kadar timbal antara hasil perkalian konsentrasi dan volume sampel dengan berat sampel. Hasil kadar timbal dalam sampel (bobot kering) dinyatakan pada tabel 4 berikut :

Tabel 4.Hasil Kadar Timbal ( $\mathrm{Pb})$ dalam Sampel (bobot kering) (mg/kg)

\begin{tabular}{cccccc}
\hline No & Sampel & $\begin{array}{c}\text { Konsentrasi } \\
\text { Sampel }(\mathrm{mg} / \mathrm{L})\end{array}$ & $\begin{array}{c}\text { Volume } \\
\text { Sampel }(\mathrm{mL})\end{array}$ & $\begin{array}{c}\text { Massa } \\
\text { Sampel }(\mathrm{g})\end{array}$ & $\begin{array}{c}\text { Bobot } \\
\text { Kering }(\mathrm{mg} / \mathrm{kg})\end{array}$ \\
\hline 1 & A & 0,08837 & 25 & 0,3 & 7,3642 \\
2 & B & 0,03859 & 25 & 0,3 & 3,2158 \\
3 & C & 0,05352 & 25 & 0,3 & 4,46 \\
4 & D & 0,02863 & 25 & 0,3 & 2,3858 \\
5 & E & 0,03112 & 25 & 0,3 & 2,5933 \\
\hline
\end{tabular}

Penentuan Kadar Timbal (Pb) dalam sampel (bobot basah) (mg/kg)

Kadar Timbal $(\mathrm{Pb})$ dalam sampel (bobot basah) $(\mathrm{mg} / \mathrm{kg})$ merupakan kadar timbal $(\mathrm{Pb})$ yang sebenarnya yang terdapat dalam sampel cabai. Hasil ini diperoleh dengan memperhitungkan persentase susut pengeringan yang dialami masing-masing sampel. Hasil Persentase susut pengeringan sampel ditunjukkan pada tabel 5 berikut :

Tabel 5. Persentase Susut Pengeringan Sampel

\begin{tabular}{ccccc}
\hline No & Sampel & Massa Basah $(\mathrm{g})$ & Massa Kering $(\mathrm{g})$ & \% Susut Pengeringan \\
\hline 1 & A & 10 & 1 & 90 \\
2 & B & 10 & 1 & 90 \\
3 & C & 10 & 1 & 90 \\
4 & D & 10 & 1 & 90 \\
5 & E & 10 & 1 & 90 \\
\hline
\end{tabular}

Setelah diperoleh persentase susut timbal dalam sampel (bobot basah) (mg/kg) pengeringan maka didapatkan hasil kadar seperti ditunnjukkan pada tabel 6 berikut:

Tabel 6. Kadar Timbal $(\mathrm{Pb})$ dalam sampel (bobot basah) $(\mathrm{mg} / \mathrm{kg})$

\begin{tabular}{rcccc}
\hline No & Sampel & Bobot Kering $(\mathrm{mg} / \mathrm{kg})$ & \% Susut Pengeringan & Bobot Basah $(\mathrm{mg} / \mathrm{kg})$ \\
\hline 1 & A & 7,3642 & 90 & 0,73642 \\
2 & B & 3,2158 & 90 & 0,3216 \\
3 & C & 4,46 & 90 & 0,4460 \\
4 & D & 2,3858 & 90 & 0,2386 \\
5 & E & 2,5933 & 90 & 0,2593 \\
\hline
\end{tabular}


Dari 5 sampel cabai yang telah dianalisis dapat diketahui kadar timbal terendah terdapat pada sampel D yaitu $0,2386 \mathrm{mg} / \mathrm{kg}$ dan kadar timbal tertinggi pada sampel A yaitu 0,73642 $\mathrm{mg} / \mathrm{kg}$. Dari hasil tersebut juga dapat dinyatakan bahwa ada 4 sampel cabai yang kadar timbalnya kurang dari $0,5 \mathrm{mg} / \mathrm{kg}$ yaitu sampel B $(0,3216 \mathrm{mg} / \mathrm{kg})$, sampel C $(0,4460$ $\mathrm{mg} / \mathrm{kg})$, sampel D $(0,2386 \mathrm{mg} / \mathrm{kg})$ dan sampel E $(0,2593 \mathrm{mg} / \mathrm{kg})$, sementara sampel A kadar timbalnya telah melebihi $0,5 \mathrm{mg} / \mathrm{kg}$ yaitu $0,73642 \mathrm{mg} / \mathrm{kg}$. Hasil tersebut menunjukkan bahwa kadar timbal pada sampel A telah melebihi nilai batas yang ditetapkan oleh Badan standardisasi Nasional.

Tingginya kadar timbal pada sambel A diduga disebabkan oleh terkontaminasinya cabai dengan logam timbal yang berasal dari polusi udara yang berasal dari gas buangan sisa pembakaran bahan bakar kendaraan bermotor. Bahan bakar kendaraan bermotor (bensin) mengandung zat aditif tetraetiltimbal atau tetrametil timbal atau campuran keduanya. Zat aditif ini berfungsi sebagai zat anti ketuk pada mesin kendaraan bermotor. Selain itu pada bensin juga ditambahkan senyawa etilen klorida dan etilen bromida. Selama proses pembakaran didalam mesin akan dikeluarkan hasil sampingan berupa timbal diklorida dan timbal dibromida yang dikeluarkan bersamaan dengan asap kendaraan bermotor. Menurut Pallar (1994) senyawa timbal sisa pembakaran bahan bakar kendaraan bermotor ini akan membentuk partikulat dan diserap oleh tumbuh-tumbuhan. Hasil penelitian Yandrilita (2015) juga menunjukkan bahwa kandungan timbal pada tanaman tomat yang ditanam pada jarak 3,5 m dari jalan raya lebih tinggi dibandingkan tomat dengan jarak tanam $20 \mathrm{~m}$ dan $500 \mathrm{~m}$ dari jalan raya.

Faktor lain yang bisa menyebabkan tingginya kadar timbal pada sampel A adalah proses pemupukan tanah yang terus menerus dilakukan oleh petani dengan tujuan meningkatkan kesuburan tanah. Pupuk sebagai sumber pencemar timbal dilaporkan oleh Charlena (2004). Pupuk yang biasa digunakan oleh petani di Indonesia adalah pupuk fosfat yang mengandung timbal berkisar $5-156 \mathrm{mg} / \mathrm{kg}$,
Pemupukan secara terus menerus mengakibatkan timbal terakumulasi didalam tanah, diserap oleh akar tanaman dan diteruskan ke jaringan tanaman. Erita Hayati (2010) menyatakan lahan yang telah terakumulasi oleh logam berat jika ditanami dengan tanaman maka logam tersebut juga akan terakumulasi dalam jaringan tanaman. Secara umum ada 2 mekanisme masuknya timbal $(\mathrm{Pb})$ tersedia dalam tanaman yaitu pengambilan melalui akar dan pengambilan melalui daun. Setelah masuk kedalam sistem, $\mathrm{Pb}$ akan diikat oleh membran sel, mitokondria dan kloroplas. $\mathrm{Pb}$ diserap secara cepat pada saat zat itu dipindahkan atau jika akarnya mati. Menurut Alloway (1990) beberapa faktor yang mempengaruhi jumlah logam berat dalam jaringan tanaman antara lain konsentrasi logam berat dalam larutan tanah, mobilitas ion logam berat ke zona perakaran, pergerakan logam berat dari permukaan akar kedalam akar tanaman dan pergerakan logam berat dalam jaringan tanaman lainnya.

\section{KESIMPULAN}

Dari penelitian yang telah dilakukan dapat diambil kesimpulan bahwa dari lima sampel cabai yang telah dianalisis, satu sampel cabai tidak memenuhi kriteria aman sesuai manajemen mutu pangan. Hal ini disebabkan karena kandungan timbal pada sampel tersebut telah melewati nilai batas maksimum cemaran logam berat dalam pangan seperti yang telah ditetapkan oleh Badan Standardisasi Nasional yaitu batas maksimum cemaran logam timbal dalam sayur, buah dan hasil olahannya adalah $0,5 \mathrm{mg} / \mathrm{kg}$. Sedangkan empat sampel cabai lainnya berada dalam kriteria aman karena kadar timbalnya kurang dari $0,5 \mathrm{mg} / \mathrm{kg}$.

\section{DAFTAR KEPUSTAKAAN}

Alloway B J. 1990. Heavy Metal in Soil. Blackie academic \& professional. Glasgow, London. 
Khaira, K. 2017. Analisis Kandungan Logam Berat Timbal (Pb) pada Cabai Merah (capsicum annumm l) yang Beredar di Pasar Batusangkar. Journal of Sainstek 9(2): 94-102

Badan Standardisasi Nasional. 2009. SNI 7387:2009. Batas Maksimum Cemaran Logam Berat dalam Pangan.

Badan Standardisasi Nasional. 2011. SNI 2354.5-2011. Cara Uji Kimia Bagian 5.

Berita Resmi Statistik BPS Provinsi Sumatera Barat. No. 46/8/13 Th XVII tanggal 04 Agustus 2014. Produksi Cabai Besar, Cabai Rawit dan Bawang Merah Tahun 2013.

Buletin Teknopro Hortikultura. Edisi 65, Januari 2004. Cabai Merah.

Charlena. 2004. Pencemaran Logam Berat Timbal $(\mathrm{Pb})$ dan Cadmium $(\mathrm{Cd})$ pada Sayur-Sayuran. Falsafah sains. Program Pasca Sarjana S3 IPB. Posted tanggal 30 Desember 2004. Diakses tanggal 04 Maret 2015.

Winarti C \& Muskiyah. 2010. Status Kontaminan pada Sayuran dan Upaya Pengendaliannya di Indonesia. Pengembangan Inovasi Pertanian 3 (3) $2010: 227-237$

Dachriyanus. 2004. Analisis Struktur Senyawa Organik Secara Spektroskopi. Padang : Andalas University Press.

Priandoko EA, Parwanayono S Ni Md, Sundra IK. 2012. Kandungan Logam Berat $(\mathrm{Pb}$ dan Cd) pada Sawi Hijau (Brassica rapa l. SuDbsp. Perviridis Bailey dan Wortel (Daucus Carrota L. Var Satifa Hoffm) yang Beredar di Pasar Kota Denpasar. Jurnal Simbiosis I (1) : 9-20

Hayati E. 2010. Pengaruh Pupuk Organik dan Anorganik terhadap Kandungan Logam Berat dalam tanah dan Jaringan Selada. $J$. Floratek 5 : 113-123

Harris DC \& Daniel. 1978. Quanittative Chemical Analysis. Newyork : W.H.Freeman and Company.

Khopkar S M. 2002. Konsep dasar Ilmu Kimia. Jakarta : UI Press

Pallar H. 1994. Pencemaran dan Toksikologi Logam Berat. Jakarta : Rineka Cipta.

Yola R, Zulfarman \& Refilda. 2013. Penentuan Kandungan Capsaicin pada Berbagai Buah Cabai (Capsicum) dengan Metoda Kromatografi Cair Kinerja Tinggi (KCKT). Jurnal Kimia UNAND. Vol.2 No.2 Mei 2013

Widianingrum, Muskiyah dan Suismono 2007.. Bahaya Kontaminasi Logam Berat dalam Sayuran dan Alternatif Pencegahannya. Buletin Teknologi Pascapanen Pertanian Vol.3.2007

Sanra Y, Hanifah TA, Bali S. 2015. Analisis Kandungan Logam Timbal pada Tanaman Tomat (Solanum Lycopersicum L) yang Ditanam di Pinggir Jalan Raya Kecamatan Aur Birugo Tigo Baleh Bukittinggi. JOM FMIPA. Vol 2. No.1 Februari 2015 